\title{
地震時における鉄骨構造骨組の \\ SEISMIC DAMAGE PREDICTION OF 柱, 梁, 接合部パネルの損傷予測 COLUMNS, BEAMS AND JOINT PANEL ZONES IN STEEL RIGID FRAMES
}

\section{長谷川 隆——1}

キーワード

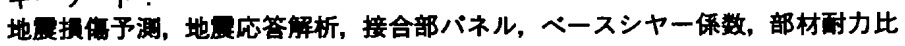

Keywords :

Seismic damage prediction, Earthquake response analysis, Joint panel zone, Base shear coefficient, Relative member strength
Takashi HASEGAWA — $* 1$

In this paper, a method for seismic damage prediction of columns, beams and joint panel zones in steel rigid frames was proposed utilizing the results of the earthquake response analysis. In order to evaluate the applicability of the proposed damage prediction method, the damage prediction and the earthquake response analysis of three different configuration frames were carried out. Comparing the results of the prediction and the earthquake response analysis, it was found that the proposed method could approximately make a safety-side estimation of the members' damage obtained from the earthquake response analysis.

\section{1.はじめに}

1995年の兵庫県南部地霆で観察された鉄骨構造建物の典型的な被 害として、梁端部の脆性的破断が挙げられる 1。このような梁端部 の破断を防止するためには、設計段階において、骨組の梁端部に生 しると考えられる損伤を把握し、それより大きな塑性変形能力を有 する部材を割り当てておくことが必要であろう。

地展時における鉄骨構造建物の梁端部の損伤は、地震動の特性や 大きさに影帮されるのは当然であるが、接合部バネル（以下、パネ ルと呼ぶ)でのエネルギー吸収の有無も影䇾する。兵庫県南部地震 で被害を受けた鉄骨構造建物の中にも、梁端部の破断とともにバネ ルが塑性化している被害があった2)。その建物の柱梁接合部の被害 状況を観察すると、梁だけが破断している場合、パネルだけが降伏 している場合、梁の破断とパネルの降伏の再方が生じる場合が見ら れた。このような被害状況からは、骨組に生じる損伤を部材レベル で予測するためには、それぞれの柱梁接合部毎に、バネル部分で吸 収するエネルギー（損儌）も考虑することによって、柱、梁部材に 生じる損伤が正確に予测できると考えられる。

地震時における鉄骨椪造建物の損伤予測に関しては、せん断型多 質点系の損伤分布則に関する研究 ${ }^{3)}$-6) や、骨組の崩壤形と柱や梁 の損伤の大きさの関係に関する検討7)、8) が行なわれている。しか し、これまでの研究では、骨組の柱、梁、バネルそれぞれに生じる 損伤を予测する方法は、必ずしも明確に示されていない。

そこで、本諭文では、設計者が地震時における鉄骨構造骨組の各 部材の損伤を把握するための手段として、骨組を構成する柱、梁、 パネルの損伤を予测する方法を提案する。この損伤予测法は、柱、 梁、パネルの損伤が、柱、梁、バネル相互の拺力比（柱 - 梁 - バネ

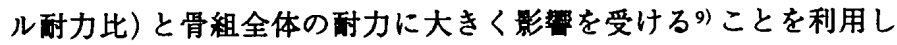

たものであり、柱 - 梁 - バネル耐力比と骨組全体の耐力を変化させ た骨組の地应応答解析を行い、その結果を直接利用して骨組各部材 の損伤を予測するものである。

提案した方法を使って、試設計骨組の損伤予测を行い、損伤予測 で得られた結果とこの骨組の地尿応答解析結果とを比較することに よって、提案した損儌予測法の妥当性を検証する。

\section{2. 骨組の损伤分布に及ぼす柱 - 梁 - バネル耐力比の影篦}

ここでは、柱 - 梁 - パネル柇力比と骨組全体の耐力を変化させた 骨組の地厐応答解析を行い、骨組各部材の損伤と柱 - 梁 - バネル耐 力比及び骨組全体の耐力との定量的関係を明らかにする。

\section{1 解析方法}

図 1 にここで使う解析モテルを示す。無限均等を想定した 5 層 骨組である。柱、梁の材端部及びバネルに弾塑性ヒンジを持ち、そ の復元力特性として、図 2 に示すようなバイリニア型を仮定した。 その 2 次勾眍は、柱、梁、バネルとも $2 \%$ とした。

表 1 に、解析骨組設定のためのパラメーターを示す。骨組全体の 耐力をベースシャー係数 $\left(\alpha_{1}\right)$ で設定し、柱-梁-パネル耐力比を、 柱/梁耐力比 $\left(R_{c}\right)$ 及びバネル耐力比 $\left(R_{p}\right)$ で設定する。ベースシ ヤー係数 $\left(\alpha_{1}\right)$ は第 1 層の設計用層せん断力 $\left(Q_{y 1}\right)$ を骨組全体の 重量 $\left(W_{t}\right)$ で除した値。柱/梁耐力比 $\left(R_{c}\right)$ は、1つの節点の上下 の柱の耐力の和 $\left(\Sigma_{C} M_{p}\right)$ を梁酎力 $\left({ }_{B} M_{p}\right)$ で除した值。バネル耐力 比は、パネルの降伏モーメント $\left({ }_{P} M_{p}\right)$ を ${ }_{B} M_{p}$ と $\Sigma_{C} M_{p}$ の小さい方で 除した値である。各層の重量 $\left(W_{i}\right)$ は24.5tonとした。

これらのバラメーターを表1で示す範囲で変化させ、図3で示す 方法で、様々な部材涌力を有する解析骨組を設定する。図中の基本 骨組とは、各居の設計用せん断力 $\left(Q_{y i}\right)$ を、ベースシヤー係数 $\left(\alpha_{1}\right)$ 


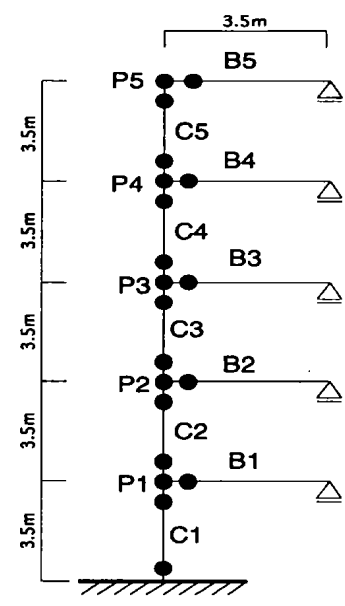

図 1 解析モデル
表1 解析パラメーター

\begin{tabular}{|l|c|c|}
\hline 解析バラメーター & 基本骨組 & 解析骨組 \\
\hline ベースシヤー保数 $\left(\alpha_{1}\right)$ & 0.25 & $0.15 \sim 0.80$ \\
\hline 柱/梁䃑力比 $\left(R_{c}\right)$ & 1.0 & $0.5 \sim 2.0$ \\
\hline バネル耐力比 $\left(R_{P}\right)$ & 1.0 & $0.4 \sim 2.0$ \\
\hline
\end{tabular}

表2 入力地展動一覧

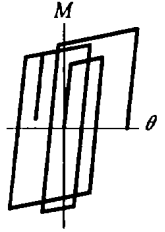

\begin{tabular}{|c|c|c|c|}
\hline 地震的 & 最大速应 & 影大加速度 & 継糛時間 \\
\hline El Centro NS & $66 \mathrm{~cm} / \mathrm{sec}$ & $679 \mathrm{Gal}$ & 10sec. \\
\hline Hachinohe EW & $52 \mathrm{~cm} / \mathrm{sec}$. & 265Gal & $16 \mathrm{sec}$. \\
\hline wv_elns & $73 \mathrm{~cm} / \mathrm{sec}$ & $402 \mathrm{Gal}$ & 30sec. \\
\hline
\end{tabular}

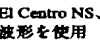
図 2 部材の復元力特性

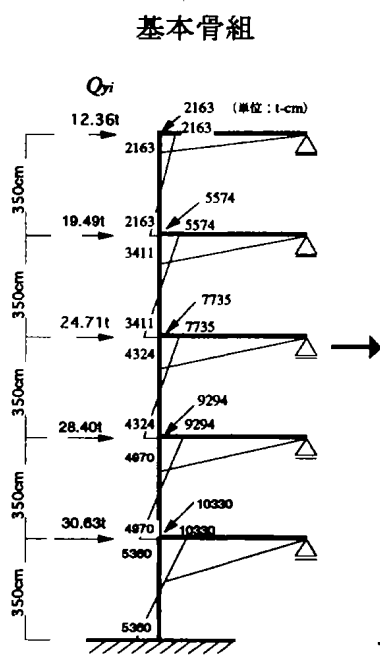

解析骨組

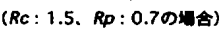

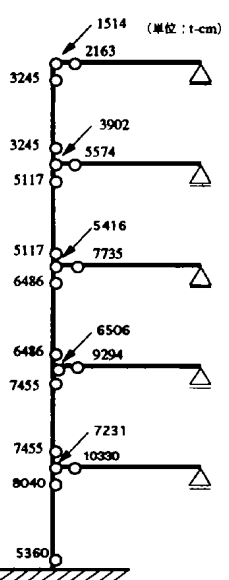

図 3 解析骨組の設定方法

0.25 の Ai 分布で設定し、それに対して柱長さの半分を反曲点にし てモーメント図を描き、その時各部材に生じるモーメントを部材 和力として有する骨組を言う。部材㴊性の設定方法の詳細は文献 9)に示す。この基本骨組の柱耐力を $R_{c}$ 倍、パネル涌力を $R_{p}$ 倍する ことによって、様々な柱 - 梁-バネル甪力比の解析骨租が設定され ろ。このようにして設定された基本骨組の固有周期は 1.18 秒であ り、解析骨組においても、部材㓮性を変化させていないので、同 一の固有周期である。

表2に応答解析で使用する入力地震動とそれらの最大速度、最大 加速度等を示す。wv_elns は人工地震波 ${ }^{10)}$ である。これらの地䟭動 の最大加速度は、図3で示す基本骨組の応答解析を行って、基本骨 組への損伤に寄与するエネルギー入力の速度換算值 $\left(V_{D}\right)^{3)}$ が

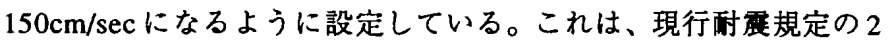
種地盤上で想定される入力レベルに相当する ${ }^{8)}$ ものとして設定し た。解析における骨組の滅衰定数は、2\%剛性比例型とした。

\section{2 解析結果}

表 3（a）〜（d）は、応答解析の結果得られた、骨組の柱/梁耐 力比 $\left(\boldsymbol{R}_{c}\right)$ 及びパネル憗力比 $\left(\boldsymbol{R}_{p}\right)$ と各部材（梁、パネル、柱、柱 脚）の損伤 $(\bar{\eta})$ の関係をベースシャー係数 $\left(\alpha_{1}\right)$ 毎に示したもの である。表 3 (a) は、 $\alpha_{1}$ が 0.25 の場合であり、(b)、(c)、(d) は、 0.30、0.35、0.40の䊅果である。表中では、梁、バネル、柱、柱脚 の記号を、それぞれB、P、C、CBで示している。1階柱脚部は、他 の柱部位に比べて、損賃が特に大きくなる場合が多いため、1階柱 脚部を他の柱と区別して表示した。

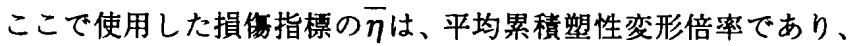
次式で定義される值である。

$$
\bar{\eta}=\frac{1}{2} \cdot \frac{W}{M_{p} \cdot \theta_{p}}
$$

ここで、Wは部材端部またはバネルの正側と負側の履歴吸収エネル

表 3 (a) 柱 - 梁 - バネル甪力比と各部材の損伤 $(\bar{\eta})$ の関係 $\left(\alpha_{1}: 0.25\right.$ の場合)

\begin{tabular}{|c|c|c|c|c|c|c|c|c|c|c|c|c|c|c|c|c|c|c|c|c|c|c|c|c|c|c|c|c|c|}
\hline \multirow{3}{*}{\multicolumn{2}{|c|}{$\begin{array}{r}\alpha_{1}= \\
0.25\end{array}$}} & \multicolumn{28}{|c|}{$\boldsymbol{R}_{\boldsymbol{p}}$} \\
\hline & & \multicolumn{4}{|c|}{0.4} & \multicolumn{4}{|c|}{0.6} & \multicolumn{4}{|c|}{0.7} & \multicolumn{4}{|c|}{0.8} & \multicolumn{4}{|c|}{0.9} & \multicolumn{4}{|c|}{1.0} & \multicolumn{4}{|c|}{$1.1-$} \\
\hline & & & & C & CB & B & P： & C & : CB & & P : & c: & :CB & & : $\mathbf{P}$ : & c: & $C B$ & B & $\mathbf{P}$ & : c : & $: \mathrm{CB}$ & & $\mathbf{P}$ & : c : & $: \mathbf{C B}$ & & : $\mathbf{P}$ & $\therefore c$ & $: \mathrm{CB}$ \\
\hline \multirow{8}{*}{$R_{c}$} & -0.91 & o & 82 & 2 & & & $37:$ & 3 & 5 & 0 & 26: & $5:$ & $: 6$ & o: & $: 15:$ & 7 & & & 7 & $: 9:$ & $: 10$ & 0 & 1 & 11 & $: 11$ & & $: 0$ & $: 11$ & $1: 11$ \\
\hline & 1.0 & o & 82 & 2 & 2 & 0 & 37: & 3 & 5 & 0 & $26:$ & 5: & 6 & & 15 & 7 & & 3 & 7 & $9:$ & 10 & 5 & 1 & 9 & 11 & & 0 & 9 & 11 \\
\hline & 1.1 & o & 86 & 1 & 2 & 0 & $38:$ & 2 & 5 & 2 & $26:$ & $3:$ & 7 & 4 & 15 & 4 & 9 & 8 & 8 & $6:$ & 10 & 11 & 2 & 7 & & 12 & 0 & 7 & $: 11$ \\
\hline & 1.2 & o & 87 & 1 & 2 & 0 & 40: & 1 & 5 & 1 & $26:$ & $2:$ & 7 & & 15 & 3 & 9 & 9 & 8 & $4:$ & $: 10$ & 12 & 2 & 4 & $: 11$ & & 0 & 4 & 11 \\
\hline & 1.4 & o & 90 & 0 & & 0 & 41: & 1 & 5 & 2 & 26 & $1:$ & 7 & $5:$ & 15 & 1 & & 9 & 8 & $1:$ & $: 10$ & 12 & $2:$ & $2:$ & $: 11$ & & :o & $: 2$ & $: 11$ \\
\hline & 1.6 & o & 90 & 0 & & & 42: & 0 & & & 26 & o: & & & $: 15$ & 1 & 9 & 9 & 8 & 1 & 10 & 12 & 2 & $: 1$ & & & $: 0$ & 1 & $: 10$ \\
\hline & 1.8 & o & 90 & 0 & 2 & 0 & 41 & 0 & 5 & 2 & 27 & o: & 7 & 5 & 15 & 0 & 9 & 9 & 8 & 0 & 10 & 12 & 2 & 0 & 10 & 13 & 0 & 0 & 10 \\
\hline & $2.0 \sim$ & o & 90 & 0 & 2 & 0 & $42:$ & 0 & 5 & 2 & 27 & о : & 7 & 5 & 15 & 0 & 9 & 9 & 8 & 0 & 10 & 12 & 2 & 0 & 10 & & 0 & 0 & 10 \\
\hline
\end{tabular}

表 3 （b）柱 - 梁 - バネル涌力比と各部材の損軞 $(\bar{\eta})$ の関係 $\left(\alpha_{1}: 0.30\right.$ の場合 $)$

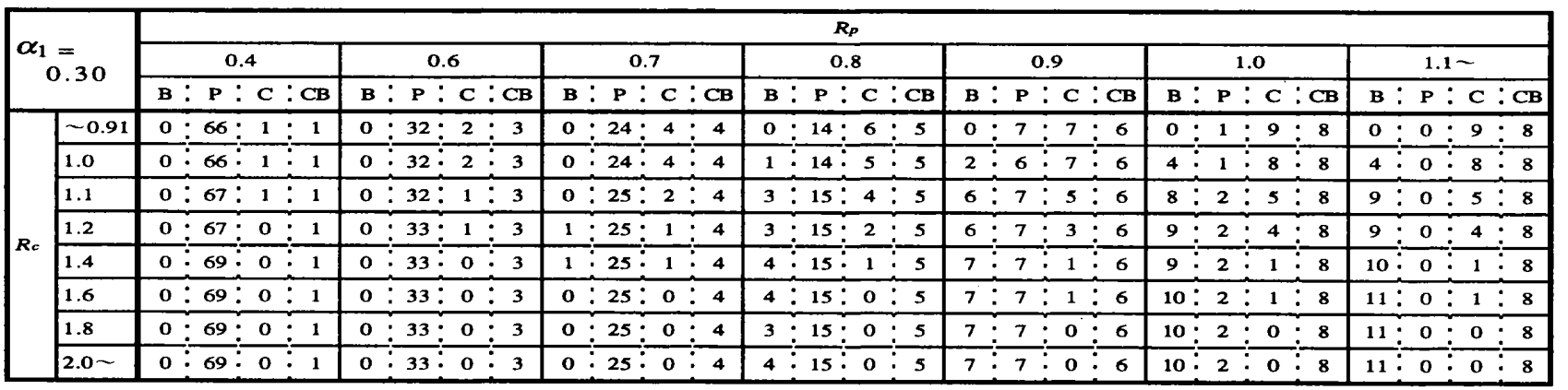


表 3 (c) 柱-梁-パネル耐力比と各部材の損伤 $(\bar{\eta})$ の夙係（ $\alpha_{1}: 0.35$ の場合）

\begin{tabular}{|c|c|c|c|c|c|c|c|c|c|c|c|c|c|c|c|c|c|c|c|c|c|c|c|c|c|c|c|c|c|c|}
\hline \multirow{3}{*}{\multicolumn{2}{|c|}{$\begin{array}{c}\alpha_{1}= \\
0.35\end{array}$}} & \multicolumn{29}{|c|}{$\boldsymbol{R}_{\boldsymbol{p}}$} \\
\hline & & \multicolumn{4}{|c|}{0.4} & \multicolumn{4}{|c|}{0.6} & \multicolumn{4}{|c|}{0.7} & \multicolumn{4}{|c|}{0.8} & \multicolumn{4}{|c|}{0.9} & \multicolumn{5}{|c|}{1.0} & \multicolumn{4}{|c|}{$1.1 \sim$} \\
\hline & & B & $\mathbf{P}$ & C & CB & B & $\mathbf{P}:$ & C & $\mathrm{CB}$ & B & $\mathbf{P}:$ & c: & :CB & B & $\mathbf{P}:$ & c: & $C B$ & $\mathbf{B}$ & $\mathbf{P}$ & $\mathrm{C}$ & $\mathrm{CB}$ & B & $\mathbf{P}$ & $: c$ & & $\mathrm{CB}$ & B & $\mathbf{P}$ & C & $\mathrm{CB}$ \\
\hline \multirow{7}{*}{$R_{c}$} & -0.91 & o & 51 & 1 & 0 & $\overline{0}$ & $26:$ & 1 & 2 & 0 & $21:$ & $3:$ & 22 & 0 & $14:$ & 4: & 3 & & 6 & $: 6$ & 5 & 0 & 1 & 7 & & 7 & 0 & 0 & 7 & 7 \\
\hline & 1.0 & 0 & 51 & 1 & 0 & 0 & 26 & 1 & 2 & 0 & $21:$ & $3:$ & 2 & 0 & 13: & 5: & 3 & & 6 & 6 & 5 & 3 & 1 & 6 & 6 & 7 & 3 & 0 & 6 & 7 \\
\hline & 1.1 & o & 51 & 0 & 0 & 0 & 27 & 1 & 2 & 0 & 21: & 1 & 2 & 1 & $14:$ & 2 & 3 & 3 & 7 & $: 3$ & 5 & 6 & 1 & 4 & 4 & 7 & 6 & 0 & 4 & 7 \\
\hline & 1.2 & o & 51 & 0 & 0 & 0 & 28 & 1 & & 0 & 22: & 1 & & 1 & 14: & 1: & & 4 & 7 & $: 2$ & 5 & 6 & 1 & 2 & 2 & 7 & 6 & 0 & 2 & \\
\hline & 1.4 & 0 & 51 & 0 & 0 & 0 & $27:$ & 0 & 2 & 0 & 23 & 0 & 2 & 2 & $14:$ & 1 & 3 & 4 & 7 & 1 & 5 & 7 & 1 & 1 & & 7 & 7 & 0 & 1 & \\
\hline & 1.6 & o & 51 & 0 & 0 & 0 & $27:$ & 0 & 2 & 0 & $22:$ & 0 & 2 & 2 & 14 & o: & 3 & 5 & 7 & 0 & 5 & 8 & 1 & 0 & & 7 & 8 & 0 & 0 & 7 \\
\hline & $1.8 \sim$ & $\overline{0}$ & 51 & 0 & 0 & 0 & $27:$ & 0 & 2 & 0 & $22:$ & 0 & 2 & 2 & 14 & o: & 3 & 5 & 7 & $: 0$ & 5 & 8 & 1 & $: 0$ & $\overline{0}$ & 7 & 9 & 0 & 0 & 7 \\
\hline
\end{tabular}

表 3 (d) 柱 - 梁 - バネル耐力比と各部材の損伤 $(\bar{\eta})$ の関係 $\left(\alpha_{1}: 0.40\right.$ の場合 $)$

\begin{tabular}{|c|c|c|c|c|c|c|c|c|c|c|c|c|c|c|c|c|c|c|c|c|c|c|c|c|c|c|c|c|c|c|}
\hline \multirow{3}{*}{\multicolumn{2}{|c|}{$\begin{array}{l}\alpha_{1}= \\
0.40\end{array}$}} & \multicolumn{29}{|c|}{$R_{p}$} \\
\hline & & & \multicolumn{3}{|c|}{0.4} & \multicolumn{4}{|c|}{0.6} & \multicolumn{4}{|c|}{0.7} & \multicolumn{4}{|c|}{0.8} & \multicolumn{4}{|c|}{0.9} & \multicolumn{5}{|c|}{1.0} & \multicolumn{4}{|c|}{$1.1 \sim$} \\
\hline & & & : $\mathbf{P}$ & C & $\vdots \mathrm{CB}$ & B & $\mathbf{P}$ & $\mathrm{C}$ & :CB & & $\mathbf{P}$ & $: c$ : & :CB & & $\mathbf{P}:$ & C: & : CB & & $: P$ & $: \mathbf{C}$ & $: \mathbf{C B}$ & & : $\mathbf{P}$ & $:$ & $\mathrm{c}:$ & & & : P : & : C & $\vdots \mathrm{CB}$ \\
\hline \multirow{6}{*}{$K_{c}$} & $\sim 0.91$ & 0 & $\vdots 41$ & 0 & 0 & 0 & 23 & 1 & & 0 & 16 & $2:$ & $: 1$ & 0 & $12:$ & 3 & & 0 & $\vdots 6$ & 4 & 4 & 0 & 1 & & 5： & & 0 & 0 & 5 & \\
\hline & 1.0 & 0 & 41 & 0 & 0 & 0 & 23 & 1 & 1 & 0 & 16 & $2:$ & 1 & 0 & $12:$ & 3 & 2 & 1 & $\vdots 6$ & 4 & 4 & 2 & 0 & & 5: & & $2:$ & : 0 & 5 & \\
\hline & 1.1 & c & 41 & 0 & 0 & o & 24 & 1 & 1 & 0 & 17 & $1:$ & 1 & 0 & $12:$ & 1 & 2 & 2 & 6 & 2 & 4 & 4 & 1 & & 3: & & 4 & 0 & 3 & 6 \\
\hline & 1.2 & c & 41 & 0 & 0 & 0 & 23 & 0 & 1 & 0 & 18 & $1:$ & 1 & 0 & $13:$ & 1 & 2 & 2 & 6 & 1 & 4 & 4 & 1 & & $1 ：$ & 6 & 4 & 0 & 1 & 6 \\
\hline & 1.4 & C & $\vdots 41$ & 0 & 0 & o & 23 & $\mathbf{0}$ & 1 & o & 18 & 0 & 1 & 0 & $14 \vdots$ & $\mathbf{0}$ & 2 & 3 & 6 & 0 & 4 & 5 & 1 & & o： & & 6 & 0 & 0 & 6 \\
\hline & $1.6 \sim$ & c & 41 & 0 & : 0 & 0 & 24 & o & 1 & 0 & 19 & $0:$ & 1 & 0 & $14 ：$ & 0 & 2 & & : 7 & 0 & 4 & 6 & 1 & & 0 : & & & $: 0$ & 0 & 6 \\
\hline
\end{tabular}

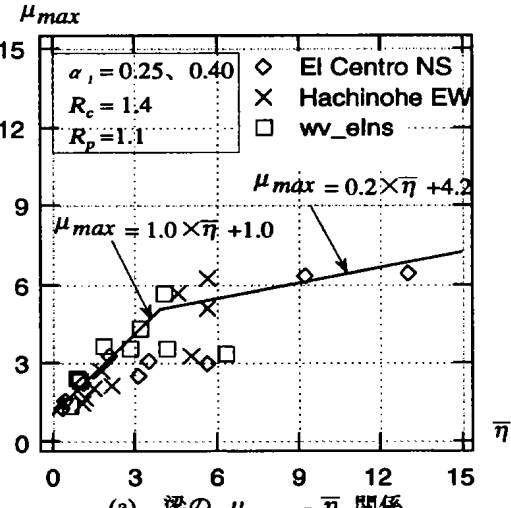

(a) 梁の $\mu_{\max }-\bar{\eta}$ 関係

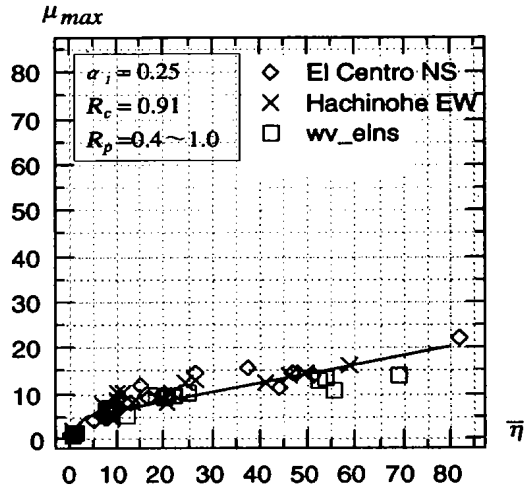

(b) バネルの $\mu_{\max }-\bar{\eta}$ 関係

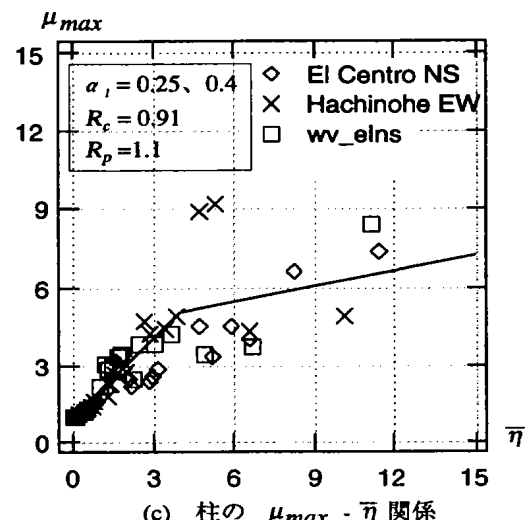

(c) 柱の $\mu_{\max }-\bar{\eta}$ 関係

図 4 部材の $\mu_{\max }-\bar{\eta}$ 成係

ギーの和、 $M_{p}$ は各部材 (パネル) の全塑性モーメント、㱠は弾性限 界回転角である。表中の $\bar{\eta} の$ 值は、各解析骨組に対して3つの地霍 動による応答解析から得られる、柱、梁、バネル、柱脚それぞれに ついての、最も大きな損伤 $(\bar{\eta})$ を示している。例えば、 $\alpha_{1}$ が 0.25 で $R_{c} 、 R_{p}$ が、それぞれ1.2、0.9の場合、梁端部（B）には損傢 $(\bar{\eta})$ の最大值として、9程度が予想されることがわかる。同様の表が、

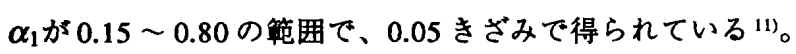

これらの結果から、 $R_{c}$ が大きくなるほど柱の損伤は小さくなり、 $\boldsymbol{R}_{\boldsymbol{p}}$ が小さくなるほど、柱及び梁の損伤が小さくなり、バネルの損 伤が大きくなることがわかる。また、 $\alpha_{1}$ が大きいほど各部材の損伤 は小さくなる。

図 4 は、応答解析から得られた梁、バネル、柱部材それそれの、

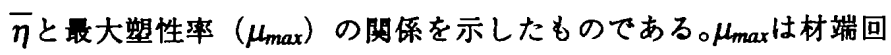
転角の最大值を弾性限界回転角（脿）で除した值である。各部材 の $\mu_{\text {max }}-\bar{\eta}$ 関係の傾向を表すものとして、次式の $\mu_{\text {max }}-\bar{\eta}$ 関係のラ インを図中に示す。

$$
\begin{aligned}
& \mu_{\max }=1.0 \times \bar{\eta}+1.0 \\
& \mu_{\max }=0.2 \times \bar{\eta}+4.2
\end{aligned}
$$

部材の損侮を表す指標として、鸟とともに $\mu_{\max }$ も重要な指標であ る。前記の式を使って、表 $3 の \bar{\eta} を \mu_{\max }$ に変換すれば、設計された 骨組の各部材（柱、梁、バネル、柱脚）に想定される 值を得ることができる。

3. 鉄骨棈造骨組の柱、梁、バネルの損偟予測法

本論文で提案する鉄骨構造骨租の損伤予測法は、「骨租への地震入 カエネルギーが決まれば、骨組各部材の損伤は、骨組のベースシ ヤー係数と各節点の柱-梁-バネル耐力比によって推定できる」とい う仮定に基づくものであり、前節の地震応答解析から得られた表 3 の柱-梁-バネル耐力比と各部材の損伤 $(\bar{\eta})$ の関係を直接利用して、 骨組各部材及びパネルの損伤を予測する。図 5 は、損伤予測の手順 である。以下に、この手順にしたがって解説する。

(1) 骨組のベースシャー係数を計算する：

(1)-1 骨組のベースシヤー係数（ $\alpha_{1} ）$ を推定する：図6で示すよj に、1階柱部材または 2 階床梁部材の全塑性モーメントの和を、階高 さ $\left(h_{1}\right)$ と建物全重量 $\left(W_{t}\right)$ で除して、ベースシャー係数 $\left(\alpha_{1}\right)$ を 算定する。図で示すように柱崩壊型では、1階柱の上下端の柇力和 
から $\alpha_{1}$ が計算されるが、梁崩壤型では、2階床梁の部材端の䣓力和 に、表 4 で示す修正係数（ $\gamma$ ）を乗じて $\alpha_{1}$ を算定する。この修正 係数は、 2 階床梁酎力和から、第 1 層の設計用せん断力 $Q_{y 1}$ を推定 するための係数である。図 3 の基本骨租で示すように、2 階床梁の 涌力は第 1 層と第 2 層の設計用せん断力によって決まるため、 $\gamma$ は 骨組の層数によって異なる值となる。例えば、図3の5層骨租の場 合、30.63 ton $=\gamma \times 10330 \mathrm{t}-\mathrm{cm} / 350 \mathrm{~cm}$ から、 $\gamma \div 1.04$ が得られ る。層数を変えて骨組の設定を行い、同様の計算を行うことによっ て、表4が得られる。なお、各節点でパネル耐力が最も小さい場合 でも、パネルは無覞して、柱と梁によって計算する。これは表 $3 の$ ベースシャー係数 $\left(\alpha_{1}\right)$ が、柱または梁の聇力によって決定されて いる值だからである。

(1)-2 5 層骨組でない場合は損伤集中の影響を考虑して（ $\left.\alpha_{1}\right)$ を修 正する $\left({ }_{N} \alpha_{1}\right):$ 一般に骨組の層数が多くなるほど損伤集中の影響が 大きくなる。文献 12）では、骨組の層数の増加による損賃集中を考 虑して、崩壊型に応じて設計用 $D s$ を增加させている。5 層骨組でな いの場合は、文献 12) で示されている傾向をおおまかにとらえた次 式によって、(1)-1で推定した $\alpha_{1}$ を修正する。

$$
{ }_{N} \alpha_{1}=\alpha_{1}+\beta \times(5-N)
$$

ここで $\beta$ は表 5 に示す值。 $N$ は層数。

(1)-3 入カレベルが $V_{D} 150 \mathrm{~cm} / \mathrm{sec}$ でない場合はN $\alpha_{1}$ を修正する (eN $\left.\alpha_{1}\right)$ : 表 3 は、骨組の $V_{D}$ 值が約 $150 \mathrm{~cm} / \mathrm{sec}$ の解析結果である。設 計者が、 $150 \mathrm{~cm} / \mathrm{sec}$ 以外の入力レベルを想定する場合は、入力エネ ルギーの速度換算値と骨組の必要耐力が比例する関係にある ${ }^{13)}$ と 仮定して、下式によって ${ }_{N} \alpha_{1}$ を修正する。

$$
{ }_{e N} \alpha_{1}={ }_{N} \alpha_{1} \times \frac{150}{V_{D}}
$$

(2) 骨組の各節点の $\boldsymbol{R}_{c}$ 及び $\boldsymbol{R}_{\boldsymbol{p}}$ を計算する:骨組のすべての柱梁接 合部について $R_{c}$ 及び $R_{p}$ を計算する。

(3) 表3を使って、骨組の ${ }_{e N} \alpha_{1}$ と各節点の $R_{c}$ 及び $R_{p}$ の值から、各節 点毎に、柱、梁、バネルの損伤 $(\bar{\eta})$ を読み取る：表 3 は $\alpha_{1}$ が 0.05 刻みで表示されているため、その間は線形補完する。

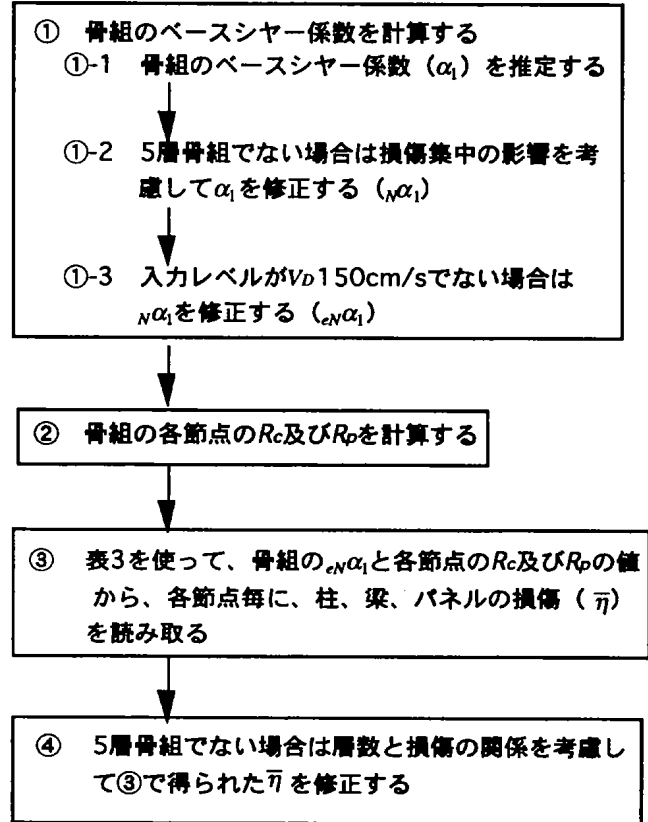

図 5 損伤予測の手順
(4) 5層骨組でない場合は層数と損伤の関係を考虑して(3で得られ た $\bar{\eta}$ 修正する:ベースシャー係数が同一で、層数が異なる骨組に おいては、骨組の $V_{D}$ 值が同一であれば、一般に低層の骨組ほど各 部材の累積塑性変形倍率 $(\eta)$ の平均值 $(a v \eta)$ が大きくなる。こ れは、（1）式で示したように、損第指標である平均累積塑性変形 倍率 $(\bar{\eta})$ が、部材の履歴吸収エネルギーを、各部材の $M_{p} \cdot \theta_{p}$ で除 すことによって得られる值であり、図3で示す方法で設定された解 析骨組では、骨組各部材の $M_{p} \cdot \theta_{p}$ の值は、層数が少ない骨組ほど、 その值が小さくなるからである。その傾向を層数之 ${ }_{a v} \eta_{N} /{ }_{a v} \eta_{5}$ の 関係で表したのが図7である。徉軸のav $\eta_{N} / a v \eta_{5}$ は5 層骨組の各部 材の $\eta$ の平均值に対する、 $N$ 層骨組の各部材の $\eta$ の平均值の比であ る。図中の○印は、図3で示す方法によって1、3、5、10層骨組を

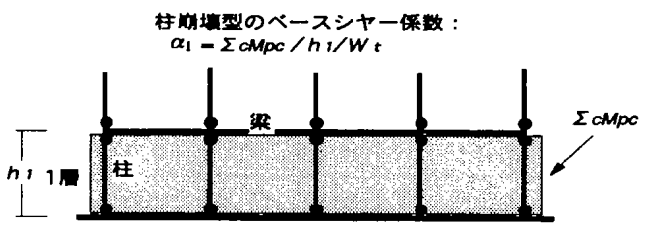

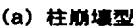

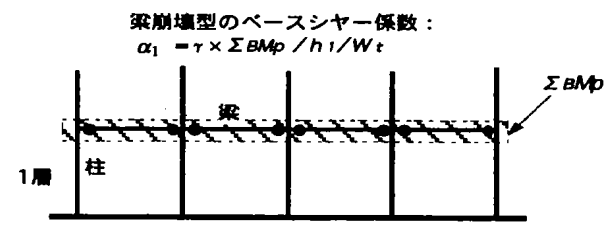

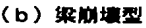

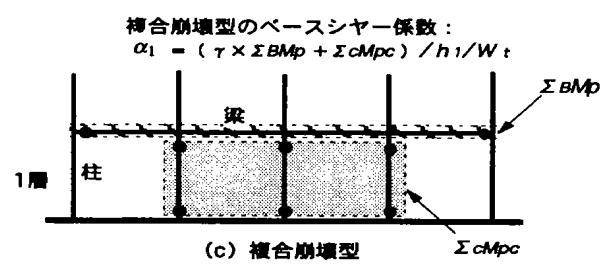

図 6 ベースシヤー係数の推定法

表 4 修正係数 $(\gamma)$

\begin{tabular}{|c|c|c|c|c|c|c|c|c|}
\hline 層数 & 1層 & 2層 & 3層 & 4層 & 5層 & 7層 & 10層 & 15層 \\
\hline 修正係数 & 2.0 & 1.20 & 1.09 & 1.06 & 1.04 & 1.03 & 1.015 & 1.007 \\
\hline
\end{tabular}

\begin{tabular}{|c|c|c|}
\hline \multirow{2}{*}{ 骨租の崩雨型 } & \multicolumn{2}{|r|}{ 届数 } \\
\hline & $N \leq 10$ & $N>10$ \\
\hline 柱崩墥型 & $\beta=0.02$ & $\beta=0.003$ \\
\hline $\begin{array}{c}\text { 粱またはバネル } \\
\text { 崩烄型 }\end{array}$ & $\beta=0.008$ & $\begin{array}{l}\beta=0.008 \text { (ただし } \\
\text { Nは常に10として } \\
\text { 浢算する) }\end{array}$ \\
\hline
\end{tabular}

表 5 損伤集中の考剫

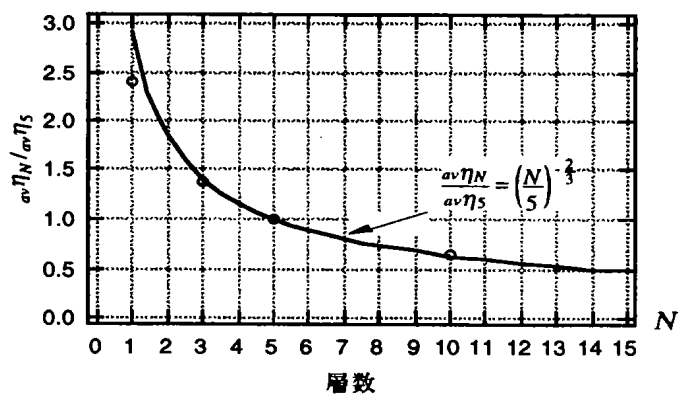

图 7 居数と損伤の関係 
同一のベースシャー係数で設定して、それらの骨組のav $\eta_{N}$ を計算 してプロットした点である。これらのプロットの傾向を表す次式 を図中に示している。

$$
\frac{a v \eta_{N}}{a v \eta_{5}}=\left(\frac{N}{5}\right)^{-\frac{2}{3}}
$$

表3は5層骨組の解析秸果から得られた值であるため、対象とする 骨組が5届でない場合、(3)で得られた各部材の損伤市は、(6) 式で 計算される倍率を乗じて修正する必要がある。このようにして、設 計された骨組の各部材及びバネルの損伤を予湘する。

ここで提案した損伤予测法は、地震応答解析から得られた表3の 結果を使って、骨組のベースシャー係数と各節点での柱-梁-パネ ル涌力比によって、各部材に想定されるの最大の損伤を予測する ものであり、骨組高さ方向の損伤分布は予測していない。したがっ て、この予測法から得られる損伤は、損伤集中が小さい層の各部 材では、かなり安全㑡の評価になる。

\section{4. 試設計骨組の損侮予測}

提案した損伤予測法は、地震応答解析から得られた表3を使って 予测するものである。表 3 の結果は、図3で示すようにAi 分布で 設阜されて、骨組の高さ方向の各節点の柱 - 梁 - バネル耐力比が全 て同一である骨組の応答解析から得られたものである。このよう な解析骨組から得られる耛果を使った損伤予測が、実断面を割り 付けて設計される鉄骨構造建物に適用できるかどうか検証するた めに、試設計骨組に対して提案した方法で損伤予測を行い、同時 に地震応答解析を行って再者を比較する。

\section{1 試設計骨組の概要}

試設計骨組は、現行耐莀基準を满足するように設計された4層骨 租で、図8で示すように架構形状が異なる3 種類である。AR-04 骨 組は、スバン長さが等しいの4スパン骨組であり、BR-04骨組は、 3スバンであるが、左右のスパン長さと真ん中のそれが異なるもの である。CR-04骨組は1スバンの骨組である。これらの骨組の設計 方針の詳細（重-等）は、文献 14)に示す。尚、これらの骨組の固 有周期は、AR-04、BR-04、CR-04骨組それぞれ、0.83 秒、0.81秒、 0.85 秒である。

\section{2 試設計骨組の損伤予測と地覆応答解析}

これらの骨組の損伤予測を行うために、前節で示した図5の手順 にしたがって、必要な計算を行う。表6は、各骨組のベースシャー 係数の計算結果である。表中のJMA Kobeの入カレベルで修正した ベースシャー係数は、後述する表8のJMA KobeのV値に基づいて (5) 式で計算したものである。表 7には、 $\mathrm{AR}-04$ 骨組の $R_{c}$ 及び $R_{p} の$ 計算結果を例として示した。これらの計算結果と表3を使って試設 計骨組各部材の損伤予測を行った。

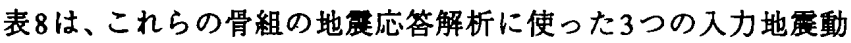
（El Centro、Hachinohe、JMA Kobe）の最大加速度とV $V_{D}$ 值である。

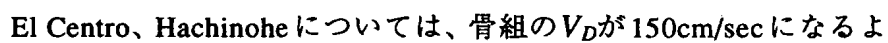
うに加速度を調整して入力しているが、JMA Kobeは原波を使用し たため、V $V_{D} か ゙ 250 \mathrm{~cm} / \mathrm{sec}$ 程度になっている。これらの入力地震動を 使った応答解析の結果と損伤予測法から得られる損伤の比較を次 に示す。解析における骨組の減衰定数は、 $2 \%$ 㓮性比例型とした。

\section{3 損偒予測と㐫答解析結果の比较}

因 9 (a) 〜 (c) に、AR-04、BR-04、CR-04骨組それぞれの各

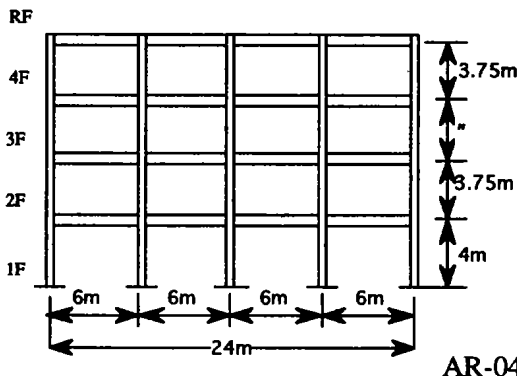

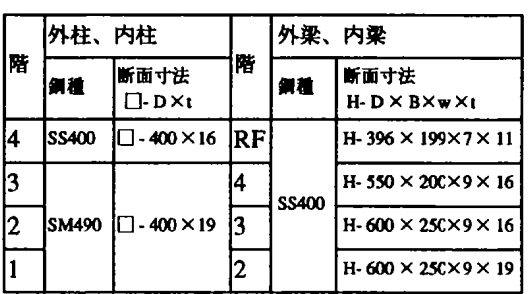

AR-04骨組

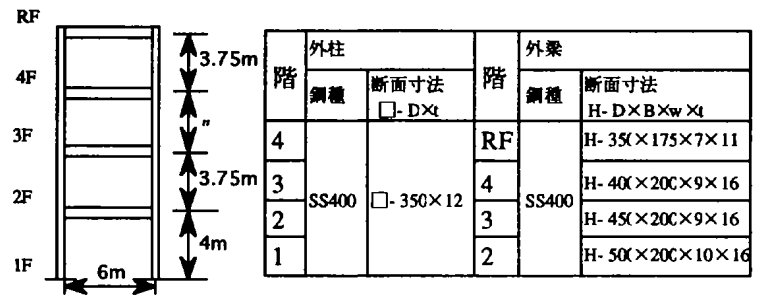

CR-04 骨組

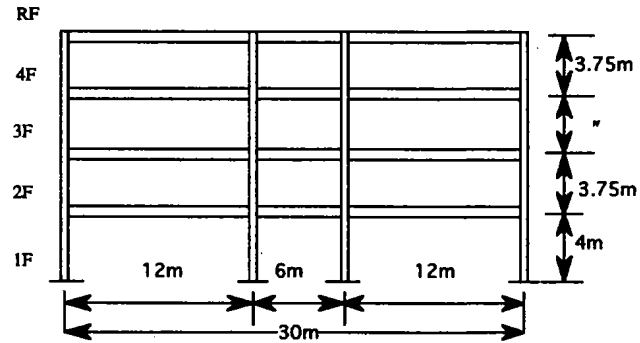

図8

図8 試設計骨組の形状

表 6 ベースシヤー係数の計算

\begin{tabular}{|c|c|c|c|}
\hline 骨組 & $\begin{array}{l}\text { ベースシャー } \\
\text { 係数 }\left(\alpha_{1}\right)\end{array}$ & 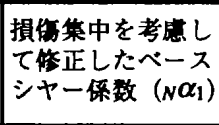 & $\begin{array}{l}\text { JMA Kobeの入力レ } \\
\text { ベルを考蚛して修正 } \\
\text { したべースシャー係 } \\
\text { 数 }\left({ }_{\mathrm{eN}} \alpha_{1}\right)\end{array}$ \\
\hline AR-04 & 0.31 & 0.32 & 0.19 \\
\hline BR-04 & 0.48 & 0.49 & 0.28 \\
\hline CR-04 & 0.30 & 0.31 & 0.19 \\
\hline
\end{tabular}

表 7 AR-04骨組の $R_{c} 、 R_{p}$ の值

\begin{tabular}{|c|c|c|c|c|}
\hline \multirow{2}{*}{ 階 } & \multicolumn{2}{|c|}{ 外柱接合部 } & \multicolumn{2}{|c|}{ 内柱接合部 } \\
\cline { 2 - 5 } & $R_{c}$ & $R_{p}$ & $R_{c}$ & $R_{p}$ \\
\hline RF & 3.06 & 2.18 & 1.53 & 1.09 \\
\hline 4F & 3.75 & 2.32 & 1.87 & 1.16 \\
\hline $3 F$ & 3.47 & 1.91 & 1.73 & 0.96 \\
\hline 2F & 3.02 & 1.67 & 1.51 & 0.84 \\
\hline
\end{tabular}

\begin{tabular}{|c|c|c|c|}
\hline 具智名 & 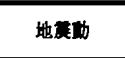 & 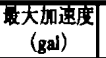 & $\begin{array}{c}V_{D} \\
(\mathrm{~cm} / \mathrm{sec})\end{array}$ \\
\hline \multirow{3}{*}{ AR-04 } & El Centro NS & 530 & 150 \\
\hline & Hachinohe EW & 320 & 150 \\
\hline & JMA Kobe NS & 818 & 252 \\
\hline \multirow{3}{*}{ BR-04 } & El Centro NS & 497 & 150 \\
\hline & Hachinohe EW & 283 & 150 \\
\hline & JMA Kobe NS & 818 & 263 \\
\hline \multirow{3}{*}{ CR-04 } & El Centro NS & 518 & 150 \\
\hline & Hachinohe EW & 285 & 150 \\
\hline & JMA Kobe NS & 818 & 245 \\
\hline
\end{tabular}



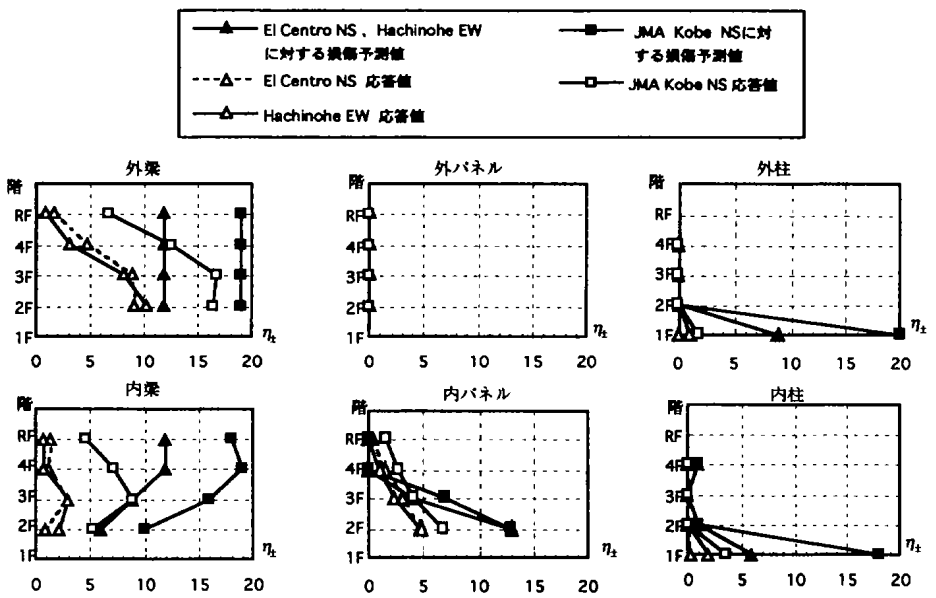

(a) AR-04胃組
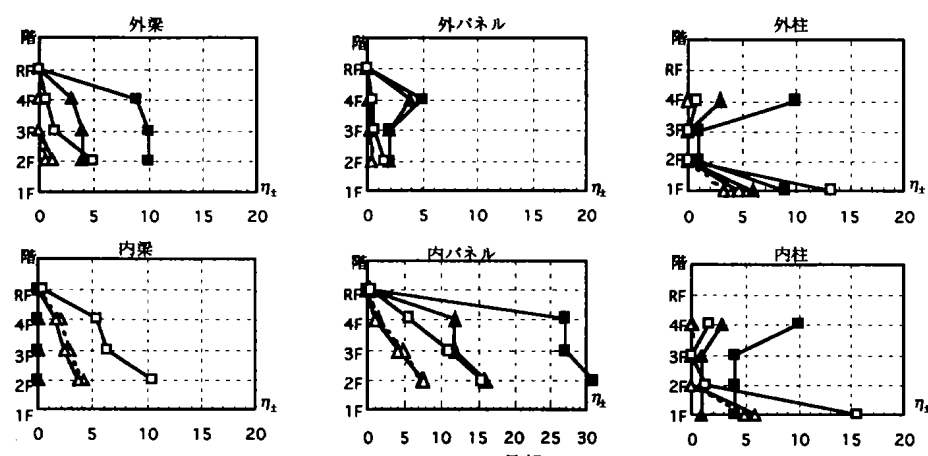

(b) BR-04骨組
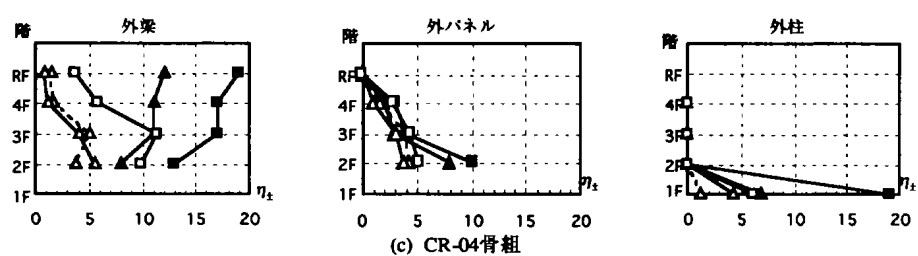

図 9 損伤予測と応答解析結果の比較

層、各部位の損伤予測の結果と応答解析の結果を比較して示す。A は El Centro、Hachinoheに対する損伤予測值で、வは地㡾応答解析 から得られた損伤值である。同様にロは、JMA Kobeに対する予測 值で、口は応答解析から得られた值である。

本論文で用いている損伤予測值は、正側と負側の損伤を平均化 した平均累積塑性変形倍率烏である。実際の骨組では、骨組と地震 動特性との関係によって、部材の正側と負側の損伤が大きく異な ることも予測されるため、ここでは試設計骨組の各部材の損伤を、 正側と負側の累積塑性変形倍率の大きい方の值 $\left(\eta_{ \pm}\right)$で示し、図

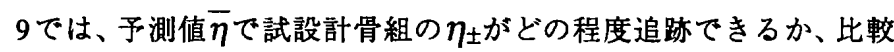
している。

AR、CR 骨組については、梁、パネル、1階柱脚の損伤を、ほほ 安全側で予測していることがわかる。一方、スパン長さが異なる BR 骨組では、内梁や内柱 1 階において、応答解析で生じる損伤を 予测できていないことがわかる。これは、スパン長の違いによる 梁剛性の影響を、本論の損伤予測法では考虑していないからであ る。これらの結果からは、1スパンまたは均等なスバンの骨組に対 しては、提案した損伤予測法によって、ほほ安全側で柱、梁、パネ ルの損伤予測が可能であることがわかる。

\section{5. まとめ}

本論文では、地震時における鉄骨構造骨組の柱、梁、パネルに 生じる損伤を予測する方法を提案した。この損伤予測法は、柱-梁パネル和力比と骨組全体の耐力を変化させた解析骨組の地震応答 解析の結果に基づいて損伤を予測するものである。この方法で、試 設計骨組の損伤予測を行い、損伤予測で得られた結果とこの骨組 の地喥応答解析結果とを比較した。得られた結論を要約して以下 に示す。

1）柱 - 梁 - バネル涌力比及び骨組全体の预力と骨組各部材の平均 累積塑性変形倍率 $(\bar{\eta})$ との定量的関係を地磨応答解析で導き、表 3に示した。また、 $\bar{\eta}$ 最大塑性率 $\left(\mu_{\max }\right)$ の関係を図4に示した。 2) 骨組のベースシヤー係数と各節点の柱/梁耐力比 $\left(\boldsymbol{R}_{c}\right)$ 及びバ ネル耐力比 $\left(R_{p}\right)$ に基づいて、表 3 を使って損修予測を行う方法 の計算手順を図5に示した。この損伤予測法では、損伤集中の影胘 や、入カレベルの大きさが考虑されている。

3）試設計骨租を対象にして、提案した損賃予測法による損伤と地 震応答解析結果を比較した結果、この損伤予测法では、1スバンま たは均等スパンの骨組では、各部材の損伤を安全側で予測できて いるが、異なるスバン長を有する骨組では、短スパンに生じた損 伤を予測できなかった。これは提案した予測法が剛性の影響を考 慮していないからである。

\section{辞辞}

本研究を進めるにあたり、日本大学教授秋山宏先生（当時東京 大学教授)に、ご指導いただきました。ここに記して、深甚なる謝 意を表します。

\section{参考文䰚}

1) 1995年兵庫県南部地震 鉄骨造建物被害調查報告書,日本建築学会近幾支部 鉄骨構造部会, 1995 年 5 月

2)長谷川隆:1995年兵車県南部地震で梁端部が破断した鉄骨造建物の弾塑性 応答性状,日本建䓩学会構造系論文集 No.498,pp129-136,1997年8月

3)秋山宏：建娼物の和震極限設計法 第 2 版, 東京大学出版会, 1987 年 4)小川厚治,黒羽啓明,上遠野明夫：強震をうける重層骨組の損伤分布に関す 万基碳的考察，日本建築学会椿造系論文集，第 479号,pp83-92,1996年 1 月 5)原田幸博:呮震下における多犋点せん断系の損侮分布則に関する解析的考 察，日本建築学会構造系論文集,No.496,pp99-103,1997 年 6 月

6)桑村仁，田村勝紀：地震による構造物のモータル損侮 - 損侮分布則の一般 化 -, 日本建築学会棈造系論文集第507号,pp79-86,1998年5月

7)竹内一郎,井上一朗、多田元英,桑村仁: 架粠の必要耐力と必要塑性変形性 能に関する一考察，日本建築学会大会学術䛨演梗概集C,pp1507-1508,1991.9

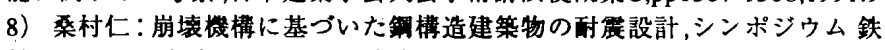
骨造における崩壊モードと吥震安全性, 日本建築学会関東支部構造部会,pp1523,1992 年 2 月

9）長谷川隆，山内泰之:強震時における中低層銅構造骨組の損傷分布に基つくく 部材の必要塑性変形能力,日本建築学会棈造系詥文集 第460号,pp167-175,1994年 6月

10) Yihua Huang,Akira Wada, Hiroki Kawai andMamoru Iwata:Study of Damage Tolerant Structure (Part4)Response Analysis of Building Shear Pole Model, 日本建築学会大会学街䜅演便概集C,pp1513-1514,1993年9月

11）長谷川隆：鉄骨棈造网接骨組の涌震性能に及にす柱-梁-バネル耐力比の 影梪に関する研究,東京大学学位詥文,1998年11月

12）建築耐震設計における保有耐力と交形性能（1990）, 日本建築学会 ,pp286,1990 年 10 月

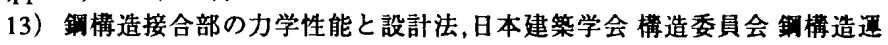
営委員会 接合小委員会,pp162,1996 年 10 月

14）井上一朗,東清仁,小川厚治,多田元英,長谷川隆：角形銅管柱 $\cdot \mathrm{H}$ 形錭梁 ラーメン構造の地震応答 (その1. 解析骨組の設計) , 日本建築学会大会学術 講演梗概集,pp269-270,1995年8月

[1999年10月 18 日原稿受理 2000 年 2 月 2 日採用決定］ 